\title{
ENGLISH TEACHERS' PEDAGOGICAL CONTENT KNOWLEDGE: THE DEGREE OF CONSISTENCY BETWEEN PERCEPTION AND IMPLEMENTATION
}

\author{
Ni Putu Diah Anggreni \\ Universitas Pendidikan Ganesha \\ diahanggreni98@gmail.com
}

IGA Lokita Purnamika Utami

Universitas Pendidikan Ganesha

lokitapurnamika@undiksha.ac.id

Kadek Sintya Dewi

Universitas Pendidikan Ganesha

sintyadewi@undiksha.ac.id

\begin{abstract}
This research aims to investigate teachers' perceptions and their implementation of Pedagogical Content Knowledge (PCK) as well as compare teachers' perceptions and implementation of PCK in teaching English for young learners. There are 3 primary school English teachers from 3 different public primary schools in Badung regency who were selected by using convenience sampling techniques. A mix-method design embedded with dominant qualitative is used in this study. In collecting the data, questionnaires, observation sheets, and interview guides were used. The data were analyzed through descriptive qualitative. The results showed that the teachers had a strong positive perception of PCK meanwhile the teachers had a very weak level in implementing pedagogical content knowledge in the class. After both of the data were compared, it found that there was a lack of consistency between the teachers' perceptions and implementation of PCK in teaching English for young learners. According to the result, it clarified that there were some problems that encountered by the teachers during teaching young learners such as problem in using English in teaching, dealing with students' different characteristics and backgrounds, having problem in using media and having a different view about strategies used.
\end{abstract}

Keywords: Primary school teacher, Perceptions, Implementation, Pedagogical Content Knowledge

\section{BACKGROUND}

Teaching English for Young Learners (TEYL) has become one of the newly developing trends in language teaching especially in the EFL context for two decades (Padmadewi, Nitiasih, \& Artini, 2009). This trend appeared by considering the importance of English as a language that is widely used around the world. According to Ghasemi and Hashemi (2011), the ability of children in learning a 
language is quicker than the adult because their brain is still naturally flexible to acquire the language. They can learn and acquire the new language as same as the way they learn their first language. Moreover, it supported by Sepyanda in 2017 who mentioned that there are two main reasons for the importance of teaching English in the primary level of learning such as the fact that English is the international language and it can help the students easier to learn English in the next level of learning. Therefore, it can be said that giving English instructions at an early age might help them to master English well.

In Indonesia, English was taught in primary school as a compulsory subject starting from grades 4 to 6 during the establishment of Kurikulum 2006 (KTSP). However, since the implementation of Kurikulum 2013, the newest national curriculum in Indonesia, English is no longer become a compulsory subject to be taught in primary school. This new policy is based on the perceptions that the primary school students in Indonesia should more focus on building their acquisition of Indonesian as the national language as well as learning its cultures and values before they learn other languages (Sepyanda, 2017). However, English as a subject still can be taught at school if it contextually needs to be taught.

In relation, there are many primary schools in Bali that still provide English as a subject since Bali is one of the famous tourism objects in Indonesia where there are many tourists from various countries who come to Bali so that having good English skills are needed. Specifically, in Badung, one of the regencies in Bali, there is a regional policy that establishes the existence of English as a subject in primary schools. According to the Regulation of Badung Regency No. 43 the Year 2016, English is needed to be learned by primary school students in Badung regency as a foreign language starting from the first until the sixth grade. Further, based on the regulation, by providing English as a foreign language in primary schools students are expected: 1) to be able to communicate in English effectively with the proper ethics and grammar; 2) to appreciate and use English as a medium of communication; 3) to use English to improve students' intellectual, emotional, and social ability; and 4) to use English in International relation.

Even though there is a regional policy that establishes the existence of teaching English in primary school especially in Badung, the elimination of English for a primary school in Kurikulum 2013 still causes several problems for the schools that still provide English as a subject for the students. Firstly, there is no national standardization (in a set of instructions) for teaching English in primary schools that leads to the confusion of the teachers about what to teach and how to teach English to their students. Secondly, English in primary school is still taught in the same way as teaching English in junior high school and senior high school level in which emphasis too many theories about the language and quite too serious. Thirdly, there are some teachers who are responsible to teach English in several primary schools do not have a special qualification to teaching English for young learners or even do not have an English Language Education background (Listyariani, 2019).

Regarding these issues, as a teacher, it is important to have good Pedagogical Content Knowledge (PCK) (Shulman, 1986; Magnusson, Krajcik, \& Borko, 1999). Pedagogical Content Knowledge refers to the combination of the teachers' knowledge about the content of the subject and the way of teaching it, based on the learners' level of learning. Shulman (1986) stated that there are 3 main aspects of pedagogical content knowledge that are needed to be had by the teachers 
namely subject matter knowledge, knowledge of learners' characteristics, and knowledge of instructional strategies. In English learning context, subject matter knowledge or content knowledge related to the teacher's knowledge about the subject that is taught in which involved language awareness and language proficiency. Language awareness is knowledge related to language such as grammar, pronunciation, vocabulary, etc. Meanwhile, language proficiency is the knowledge related to the use of language such as the ability in speaking and writing by using English (Andrews, 2001). In addition, as a teacher, knowing the learners' characteristics is also important. In this context, the teacher needs to be aware that the characteristics of young learners are different compared with adult learners (Cameron, 2001). Young learners have some unique characteristics in learning such as have a very high level of curiosity, learn by creating meaning through their experience, have short attention, and easy to get bored and focus on the real situation and context (Juhana,2014). Therefore, the teacher needs to be able to adjust with their characteristics so that the teacher can teach them effectively. Moreover, in teaching, the knowledge about instructional strategies also become other crucial aspect to achieved the objective of learning. As the purposes of the Kurikulum 2013, Suharyadi as cited in Agustini, et.al. (2019) mentioned that the learning process should be interactive, enjoyable, challenging, and motivating the learners' participation, and give them a chance to develop their ability independently based on their interest and talent. Furthermore, it is recommended to teach language contextually by facilitating the learning process with media, contextual activities, fun activities like games and songs or any other activities that can develop students' language skills (ÇAKIR, 2004; Medwell, Wray, Minns, Coates, \& Griffiths, 2009). Thus, it can be said that PCK is important as guidance for the teacher in teaching English for their students.

In relation to the theoretical framework, there are several studies that has been conducted related to teachers' pedagogical knowledge, especially in teaching English for young learners' context. Those studies focused on the use of media in TEYL (Aini, 2013), teaching English through creating positive learning environment (Artini, 2017; Putra, 2015), teacher knowledge and challenges in teaching language (La Ode Turi, Jafar Ahiri, La Dunifa, 2017; Rahayu, 2016), the used of traditional games in teaching language (Rusiana \& Nuraeningsih, 2016) and teachers' perceptions and implementation of teaching (Agustini, Artini, \& Padmadewi, 2019; Listyariani, Artini, \& Padmadewi, 2018). However, there are still few studies that emphasize the comparison between teachers' perceptions and practices in terms of pedagogical content knowledge. Therefore, research on perceptions and practices of English teachers' pedagogical content knowledge in teaching English at the primary level .needs to be conducted. Specifically, this research will examine the issue by involving some primary school English teachers in Badung regency. Further, this research will emphasis to the perceptions, implementation and comparison between the teachers' perceptions and implementation of pedagogical content knowledge (PCK) in teaching English to young learners. 


\section{METHOD}

This research employed a mixed-method research design with qualitative dominated. In this research, a set of data was elaborated with the other data to support each other. In addition, it also embedded in secondary data forms in larger studies in which have different data forms with the primary databases, and secondary databases provide a supporting role in this study (Cresswell, 2012). In addition, in order to avoid different perspectives or biases that occur from different data sources and to validate, check and completeness the existing findings, triangulation was adopted in this research (Patton, 1999; Denzin, 2015).

The research was focused on the perceptions of primary school English teachers about PCK, their effort in implementing PCK in teaching English for young learners, and the comparison between their perceptions and implementation of PCK in teaching English for young learners. Further, there are 3 primary school teachers from 3 different schools involved in this research. Those subjects were selected by using Convenience sampling techniques or availability sampling which relied on particular members of the population who were ready to participate in the study. According to Cresswell (2012), this sampling technique was used since it has easy accessibility and proximity to the researcher.

In collecting the data, there are three instruments were used namely, questionnaire, observation sheet, and interview guide. The questionnaire used to get information about the teachers' perception of PCK. The questionnaire was adopted from Listyariani (2014) consisted of 50 questions related to the components of PCK and used the Likert scale ranging from 5 to 1 . The observation sheet was used to find out the frequency of the implementation of pedagogical content knowledge by teachers during teaching English for young learners. Further, the observation were conducted twice. Moreover, the interview guide was used to get more information that needed to be clarified by the teachers especially those that related to the relationship between the teacher perceptions and implementation of pedagogical content knowledge in teaching English for young learners.

The data obtained from the questionnaires and observation sheet were analyzed quantitavely by calculating the score of each component of the PCK of each teacher. After that, the average score of all teachers was calculated and categorized based on the level of qualification proposed by Koyan (2012). After the data of perceptions and implementation have been collected, further, the relationship between both of the data was analyzed qualitatively. After that, the results were confirmed by conducting an interview with the teachers. The result of interview was analyzed by using an interactive analysis model that has been proposed by Miles and Huberman (1994). 


\section{FINDING AND DISCUSSION}

Regarding to the perceptions of primary school English teachers of PCK, the data of questionnaire were analyzed quantively and presented in table below.

Table 1. The Summary of Data of Teachers' Perceptions of PCK

\begin{tabular}{|c|c|c|c|c|c|c|}
\hline \multirow[t]{2}{*}{ No. } & \multirow{2}{*}{$\begin{array}{l}\text { Components of } \\
\text { PCK }\end{array}$} & \multicolumn{3}{|c|}{ Teachers's } & \multirow{2}{*}{$\begin{array}{l}\text { Mean Score } \\
\text { of } \\
\text { Perceptions }\end{array}$} & \multirow[t]{2}{*}{ Qualification } \\
\hline & & $\mathrm{T} 1$ & $\mathrm{~T} 2$ & T3 & & \\
\hline 1. & $\begin{array}{l}\text { The Subject Matter } \\
\text { Knowledge }\end{array}$ & 4.14 & 4.00 & 4.29 & 4.143 & Very Strong \\
\hline 2. & $\begin{array}{l}\text { The Knowledge of } \\
\text { Young Learners' } \\
\text { Characteristics }\end{array}$ & 4.17 & 3.89 & 4.11 & 4.056 & Very Strong \\
\hline 3. & $\begin{array}{l}\text { The Use of Learning } \\
\text { Strategies for } \\
\text { Young Learners }\end{array}$ & 3.76 & 3.80 & 3.36 & 3.640 & Strong \\
\hline \multicolumn{5}{|c|}{ Total } & 3.946 & Strong \\
\hline
\end{tabular}

Based on the data showed in the table above, it showed that the teachers' perceptions of pedagogical content knowledge were qualified as strong since the mean score was 3,946 in which belonged to interval 3,3335 $\leq \mathrm{M} \leq 4,0005$. Specifically, the result of the first component of PCK which is the knowledge of subject matter knowledge was 4,143 which belonged to interval 4,0005 $\leq \mathrm{M} \leq$ 5,001 , indicated that the teachers have very strong perceptions about it. The second component which is the knowledge of young learners' characteristics, the teachers also showed very high perceptions as the result was 4,056 which also belonged to interval 4,0005 $\leq \mathrm{M} \leq 5,001$. Meanwhile, the last component which is the use of instructional strategies for young learners, showed that the teachers have high perceptions since the result was 3,640 belonged to interval 3,3335 $\leq M \leq 4,0005$ and qualified as strong. Therefore, it can be implied that the teachers have positive perceptions related to pedagogical content knowledge in teaching English to young learners.

After analyzing the observation sheet, the result of the implementation of PCK by the teachers is showed in table below.

Table 2. The Summary Data of Teachers' Implementation of PCK

\begin{tabular}{|c|c|c|c|c|c|c|}
\hline \multirow[t]{2}{*}{ No. } & \multirow{2}{*}{$\begin{array}{l}\text { Components of } \\
\text { PCK }\end{array}$} & \multicolumn{3}{|c|}{ Mean Score of Frequency } & \multirow{2}{*}{$\begin{array}{l}\text { Mean Score } \\
\text { of } \\
\text { Frequency }\end{array}$} & \multirow[t]{2}{*}{ Qualification } \\
\hline & & $\mathrm{T} 1$ & $\mathrm{~T} 2$ & T3 & & \\
\hline 1. & $\begin{array}{l}\text { The Subject } \\
\text { Matter Knowledge }\end{array}$ & 20.75 & 10.00 & 18.25 & 16.330 & Strong \\
\hline 2. & $\begin{array}{l}\text { The Knowledge of } \\
\text { Young Learners' } \\
\text { Characteristics }\end{array}$ & 1.13 & 0.75 & 2.38 & 1.420 & Very weak \\
\hline 3. & $\begin{array}{l}\text { The Use of } \\
\text { Instructional } \\
\text { Strategies in } \\
\text { Teaching English } \\
\text { for } \\
\text { Learners }\end{array}$ & 1.91 & 1.82 & 3.18 & 2.300 & Very weak \\
\hline \multicolumn{5}{|c|}{ Total } & 6.684 & Very weak \\
\hline
\end{tabular}


As presented in table above, the result of the implementation of PCK by the teachers is very weak since the mean score was 6,688 in which belonged to interval $0,330 \leq \mathrm{M} \leq 6,920$. Specifically, the subject matter knowledge was categorized as high since the result was 16,330 which belonged to an interval of $15,700 \leq \mathrm{M} \leq$ 20,090. Thus, it implied that the teachers have implemented it well in the class. Whereas, the other components which were the knowledge of young learners' characteristics and the use of instructional strategies in teaching English for young learners were both qualified as very weak. The result of the knowledge of young learners' characteristics was 1,420 meanwhile the result of the use of instructional strategies was 2,300 in which both belonged to interval $0,330 \leq M \leq 6,920$. Thus, it indicated that the teachers did not implement those two components well and effectively yet when they teach English to young learners. Therefore, it can be said that in general, the teachers showed a very weak effort in implementing the pedagogical content knowledge in teaching English to young learners.

Since both of the teachers' perceptions and implementation of pedagogical content knowledge have been analyzed, further, both of the data perceptions and implementation were compared in order to find of the relationship between them. Thus, the comparison between those data can be seen in table below.

Table 3. Comparison of the Teachers' Perceptions and Implementation of Pedagogical Content Knowledge

\begin{tabular}{|c|c|c|c|c|c|c|c|c|}
\hline \multirow[t]{2}{*}{ Components of PCK } & \multicolumn{3}{|c|}{ Perceptions } & \multirow{2}{*}{$\begin{array}{l}\text { Mean } \\
\text { Score }\end{array}$} & \multicolumn{3}{|c|}{ Implementations } & \multirow{2}{*}{$\begin{array}{l}\text { Mean } \\
\text { Score }\end{array}$} \\
\hline & $\mathrm{T} 1$ & $\mathrm{~T} 2$ & T3 & & $\mathrm{T} 1$ & $\mathrm{~T} 2$ & T3 & \\
\hline $\begin{array}{l}\text { The Subject Matter } \\
\text { Knowledge }\end{array}$ & 4.14 & 4.00 & 4.29 & 4.143 & 20.75 & 10.00 & 18.25 & 16.330 \\
\hline $\begin{array}{l}\text { The Knowledge of } \\
\text { Young Learners' } \\
\text { Characteristic }\end{array}$ & 4.17 & 3.89 & 4.11 & 4.056 & 1.13 & 0.75 & 2.38 & 1.420 \\
\hline $\begin{array}{l}\text { The Use of } \\
\text { Instructional } \\
\text { Strategies in Teaching } \\
\text { English for Young } \\
\text { Learners }\end{array}$ & 3.76 & 3.80 & 3.36 & 3.640 & 1.91 & 1.82 & 3.18 & 2.300 \\
\hline \multicolumn{4}{|c|}{ Total of Mean Score } & 3.946 & \multicolumn{3}{|c|}{ Total of Mean Score } & 6.680 \\
\hline \multicolumn{4}{|c|}{ Range } & $\begin{array}{c}3.333 \\
5 \leq \mathrm{M} \\
\leq \\
4.000 \\
5\end{array}$ & \multicolumn{3}{|c|}{ Range } & $\begin{array}{c}0.330 \leq \mathrm{M} \\
\leq 6.920\end{array}$ \\
\hline \multicolumn{4}{|c|}{ Category } & High & \multicolumn{3}{|c|}{ Category } & Very Low \\
\hline
\end{tabular}

Based on data showed in Table 3, it can be seen that there was a significant difference between the teachers' perceptions and their implementation of PCK in teaching English for young learners. The result of teachers' perceptions was categorized as high meanwhile their implementation was categorized as very low. Further, the relationship between the perceptions and implementation of PCK is presented on table below. 
Table 4. The Relationships between the Teachers' Perceptions and Implementation of Pedagogical Content Knowledge

\begin{tabular}{|c|c|c|c|c|}
\hline \multirow[t]{2}{*}{ No. } & \multirow{2}{*}{$\begin{array}{l}\text { Components of } \\
\text { PCK }\end{array}$} & \multicolumn{2}{|c|}{ Categorization } & \multirow[t]{2}{*}{ Relations } \\
\hline & & Perceptions & Implementations & \\
\hline 1. & $\begin{array}{l}\text { The Subject Matter } \\
\text { Knowledge }\end{array}$ & Very high & High & $\begin{array}{c}\text { Slightly } \\
\text { consistent }\end{array}$ \\
\hline 2. & $\begin{array}{l}\text { The Knowledge of } \\
\text { Young Learners' } \\
\text { Characteristics }\end{array}$ & Very high & Very low & No consistency \\
\hline 3. & $\begin{array}{l}\text { The Use of } \\
\text { Instructional } \\
\text { Strategies in } \\
\text { Teaching English } \\
\text { for } \\
\text { Learners }\end{array}$ & High & Very low & $\begin{array}{c}\text { Lack of } \\
\text { consistency }\end{array}$ \\
\hline & PCK & High & Very low & $\begin{array}{c}\text { Lack of } \\
\text { consistency }\end{array}$ \\
\hline
\end{tabular}

The data in the table above showed that there is a lack of consistency between the perceptions and the implementation of their pedagogical content knowledge of the teachers in teaching English to young learners. It is because the result of the perceptions was high meanwhile the result of the implementation was very low. Further, when each component was compared, each component seemed to have a different consistency. The subject matter knowledge was categorized as slightly consistent since there were no significant gaps between the teachers' perceptions and the implementation of this component. On the other hand, the use of instructional strategies in teaching English for young learners was categorized as lack of consistency since there was quite far gaps between the perceptions and the implementation. Similarly with the knowledge of young learners' characteristics in which also have far gaps between the perceptions and the implementation, so it is categorized as no consistency. Furthermore, when all of the data were compared, the subject matter knowledge became the component of PCK that had a good consistency than the other two components, and the knowledge of young learners' characteristics became component that had the worst consistency compared to the others.

Referring to the result of the perceptions, it indicated that the teachers have strong perceptions of PCK in teaching English for young learners. The result of the first component of PCK which is the subject matter knowledge belonged to a very strong category of perceptions. It indicates that all of the teachers have a very good level of understanding of the subject matter knowledge in teaching English to young learners. It accordance with the result found by Swart, et.all. (2017), the teachers who have a high level of language awareness can influence the students' language comprehension so that they can learn maximally. Moreover, Canh and Renandya (2017) also found that the higher level of language proficiency teachers have, the more they are confident in teaching and can be a good role model for their students in learning English.

Similarly to the second component, the knowledge of young learners' characteristics, that also belonged to a very strong category of perceptions. It means that the teachers also have a good understanding of young learners' characteristics. 
When teachers have known about young learners' characteristics well, the teachers will be able to teach them easily. Moreover, the result in line with Astuti, Fauziati, and Marmanto (2019) in which revealed the teachers who have a good understanding of young learners' characteristics will be able to implement appropriate strategies as well as be able to achieve the learning and create effective teaching.

Meanwhile, the last component which was the use of instructional strategies in teaching English for young learners showed that the teachers' perceptions of this component belonged to a strong category of perceptions. Regarding this, even though the result of this component was not as high as the other two components, the result still indicated that the teachers also have a good understanding related to this component. As stated by ÇAKIR (2004), since young learners are different compared to adult learners, keeping such a positive classroom atmosphere can give positive engagement of the students to have the interest to expose their language input as well as practice the target language. Thus, having such good knowledge about teaching or instructional strategy means that the teachers have already known kinds of strategies that suitable to be used to teach young learners.

As the result of the implementation of PCK was 6,680 in which belonged to very low categorization. It indicated the teachers do not implement pedagogical content knowledge maximally during teaching. Regarding the implementation of the first component of PCK which is subject matter knowledge, the result showed that it categorized as a high categorization. Further, it implied that the teachers have implemented it well during teaching. It also indicated that all of the teachers gave such intensive attention to this component. As seen during the observation, the teachers often corrected the language error of the students whether error in the grammar or pronunciation. In the language learning context, being able to use appropriate grammar as well as can pronounce the word correctly have become important things to be known by the learners. Thus, as English teachers, being aware of those kinds of things might help the teacher to improve the students' language comprehension. In addition, it also found that all of the teachers also always tried to speak and write using English fluently and correctly in the class to make the students became familiar with English even though it was still dominated by Indonesian.

On the other hand, the second component of PCK, the knowledge of young learners' characteristics, the result of its implementation was categorized as very low. The result showed that the teachers seemed to not implement it maximally during teaching. In fact, all of the teachers have tried their best to adjust to the students' characteristics, and they already had their own strategies to deal with it. However, it was still not giving any significant influence on the students in learning the language. As stated by Juhana (2014), young learners consider as learners who have a high level of curiosity, learn through experiences, have short attention, and learn through context. Thus, the teachers need to be able to create learning that can give opportunities for the students to explore and learn the language through activities that fun and meaningful for them. However, from the observation, the teachers were the ones who dominated the class. All of the materials mostly explained by themselves. Thus, the students were not really had much chance to be active in the class. The students would be active only when the teacher asks them to do something based on their instruction. 
Similarly with the last component of PCK which is the use of instructional strategies to teach English for young learners". The result of this component also showed a very low qualification of implementation. It implied that the teachers showed less effort in preparing strategies and activities that can improve the students' English skills as well as improve their willingness to learn English. Based on the observation, it found that not all of the teachers used media in teaching, even when they used it, it was not used in every meeting. In addition, the use of games, songs, and other fun activities also seemed very rarely implemented because the teachers mostly focus on the content of learning.

Based on the result of the comparison of perceptions and implementation of PCK of the teachers, it showed that there was a lack of consistency between the perceptions and implementation of pedagogical content knowledge of the teachers. This result is in line with the result found by Listyariani, et.al. (2019) who found that the teachers' perceptions and their implementation of teaching English for young learners were not always consistent. At this point, they revealed that the teachers might have a good level of understanding of TEYL, however, they did not implement well in the class. Further, in order to confirm it, interviews were conducted.

The result of the comparison of the teachers' perception and implementation of the subject matter knowledge was qualified as slightly consistent. Further, it actually indicated that all of the teachers have good perceptions and practices related to the subject knowledge. In addition, it also indicated that they have high consideration for this component especially those that related to correcting the grammar error, and mispronunciation made by the students. Further, in the interview all of the teachers stressed that the students' language errors needs to be corrected to avoid bad language formation while using English. This result was in line result found by Usyal and Aydin (2017) who revealed that all of EFL teachers believe that language correction can help in improving learners' accuracy in using the language, grammar, and vocabulary knowledge, as well as pronunciation skills so that they are able to use the language appropriately. Similarly, Jing, Xiaodong, \& Yu (2016) found that teachers' correction may help the students to know what they are lacking and what kind of errors are made so that they can improve their English little by little. However, at this point, it also found that the teachers also seemed to have difficulty related to the use of English to communicate with the students in the class. From the result of perceptions, there were two teachers who preferred to use Indonesian in teaching while one teacher preferred to use English. Whereas, based on the implementation, actually, all of the teachers dominantly used Indonesian in the classroom. It implied that English is still not fully used in the class. Further, as confirmed by the teachers, there are several considerations of using English in the class such as the students are still too young, they are afraid to speak and still lack vocabulary. Thus, the teachers think that it is quite difficult to use English while teaching the students in the class. Therefore, in order to overcome the problems, the teachers only use English at a certain time and do code-switching when they think that it is difficult for the students to understand what they said. The result is in line with Madriñan (2014) who found that the teachers prefer to use both mother tongue and target language during learning in order to engage students in learning and to increase the students' understanding. Moreover, another same result found by Aminifard and Mehrpour (2019) who revealed that many teachers still 
relied on the use of mother tongue in teaching English in order to save time and dealing with students' misbehavior.

Meanwhile, the comparison of the knowledge of young learners' characteristics showed there was no consistency between its perceptions and implementation. Regarding the result of perceptions, the teachers seemed to have a very good level of perceptions in which indicated that they have good knowledge about young learners' characteristics, whereas, the result of implementation showed that the teachers did not fully engage young learners in learning. One of the teachers stated that the problem occurred since the school just provide English for the students since a year ago. Further, she added that all of the students do not have good knowledge about English in which makes her need to teach them starting from the really early level of learning. On the other hand, another teacher revealed that in the school the students also have different backgrounds that need to be cared for which makes her need to give extra care to the students to feel equal with the others. Meanwhile, the other one expressed that sometimes she is really frustrated with the students' attitude that has low motivation in learning. In addition, a lack of motivating learning activities also became a problem. Whereas, it is suggested to provide favorable learning conditions so that the students can have a positive disposition towards the process of language learning at school Sougari and Hovhannisyan (2016). As clarified by the teachers, they tended to teach the students directly or using teacher-centered, give them tasks or homework, and ask them to take notes. Besides, the teachers are also pressed by the time since they need to finish all of the material before the final test. Thus, sometimes it makes the teachers need to a little bit of a hurry in teaching in which makes the learning does not really run effective and meaningful for the students.

Based on the result, the use of instructional strategies in teaching English to young learners got a lack of consistency when the result of perceptions and implementation were compared. As stated before, during the observation, the teachers rarely use media, games, songs, and other activities that can create such a fun learning process for young learners. They mostly teach the students manually such as explain the material directly to the students or use textbook. The teachers admitted that the use of media in teaching is important. However, they also added that they also did not use it frequently in the class. As showed in the interview, some teachers stated that the media used in the class is depending on the topics that will be learned by the students. They stated that not all topics can be taught by using media and only use to make the students easier to understand the material. On the other hand, another teacher seemed to have a different view of others. She believes that the use of media is needed since it can make the students be more excited about learning. So she always tried to provide media in teaching. Moreover, they also said that they faced some difficulties in using media such as problems of students' misbehavior, difficulty in dealing with the time, and problems in using LCD and other technology so the media used are limited. Regarding this, Aini in 2013 also found that the teachers have the same difficulties in choosing and implementing instructional media for teaching. She found that the teachers still had a negative belief toward the use of instructional media. In addition, they also encountered problems in dealing with time cost allocation, availability, and appropriateness of instructional media, and also had a technical problem when utilizing the media. Besides the use of media in teaching, it also found that the teachers also have 
different ways of teaching especially related to the activities provided for the students in learning. In line with the result of perceptions in which also showed the same thing, each teacher seemed to have their own perceptions related to the technique or strategy in teaching English to young learners. Moreover, the result of the implementation also supported that the way they teach is different from each other. Since they have various perceptions related to the strategy used, their view toward the strategy is also different. At this point, the teachers' view related to the use of the game, song, and also group activities in teaching English to young learners are quite different from each other.

Further, those problems were in line with Pertiwi, Salabiyati, Damara and Pratolo (2020) who found that the teachers still have challenges in teaching young learners in which they encountered problem in using English as medium in teaching, dealing with different characteristics of the students and the use media in teaching.

\section{CONCLUSION}

According to the result of the study, it can be concluded that the teachers' perceptions of pedagogical content knowledge (PCK) is qualified as strong since the mean was 3,946 in which belonged to interval 3.3335 $\leq \mathrm{M} \leq 4.0005$. It indicated that the teachers have positive perceptions related to their pedagogical content knowledge and have very good knowledge and understanding related to pedagogical content knowledge in teaching English to young learners.

The result of the implementation of pedagogical content knowledge of the teachers was qualified as very weak since the mean score was 6,688 and belonged to interval $0,330 \leq M \leq 6,920$. Regarding this, not all of the components of PCK were implemented well in the class. It indicated that the teachers showed a very weak effort in implementing the pedagogical content knowledge in teaching English to young learners.

The comparison of perceptions and implementation of PCK of the teachers, showed that there was a lack of consistency between the perceptions and the implementation of pedagogical content knowledge of the teachers. It is because there is a huge gap between the result of perceptions and the implementation of pedagogical content knowledge of the teachers. Further, it clarified that it was caused by several problems that were encountered by the teachers such as difficulty in communicating by using English in the class, dealing with different characteristics and backgrounds of the students and having problems when using media and also have different views on activities used in teaching.

\section{REFERENCES}

Agustini, N. W. W., Artini, L. P., \& Padmadewi, N. N. (2019). English Teachers ' Perceptions and Classroom Practices On Constructivism Values in Primary Schools In Badung Regency. Jurnal Pendidikan Bahasa Inggris Indonesia, $7(2), 1-11$.

Aini, W. N. (2013). Instructional Media in Teaching English to Young Learners: A Case Study in Elementary Schools in Kuningan. Journal of English and Education, 1(1), 196-205. 
Aminifard, Y., \& Mehrpour, S. (2019). Mother Tongue Use in Young Iranian EFL Learners' Classroom : Helpful Scaffold or Debilitating Crutch ? The Reading Matrix: An International Journal, 19(2), 77-85.

Andrews, S. (2001). The language Awareness of the L2 Teacher: Its Impact upon Pedagogical Practice. Language awareness, 10(2-3), 75-90.

Artini, L. P. (2017). Rich Language Learning Environment and Young Learners' Literacy Skills in English. Lingua Cultura, 11(1), 19-24. doi: https://doi.org/10.21512/lc.v11i1.1587

Astuti, D. A., Fauziati, E., \& Marmanto, S. (2019). Celebrating Students ' Diversities Through Understanding Students ' Characteristics. International Online Journal of Education and Teaching (IOJET), 6(4), 723-731.

Cakir, I. (2004). Designing activities for young learners in EFL classrooms. Gazi Üniversitesi Gazi Eğitim Fakültesi Dergisi, 24(3).

Cameron, L. 2001. Teaching Languages to Young Learners. Cambridge: University Press.

Creswell, J.W. (2012). Educational Research Planning, Conducting, and Evaluating Quantitative and Qualitative Research. Fourth Edition. USA: Pearson Education, Inc.

Canh, V. L., \& Renandya, W. A. (2017). Teachers' English Proficiency and Classroom Language Use: A Conversation Analysis Study. RELC journal, 48(1), 67-81. doi: https://doi.org/10.1177/0033688217690935

Denzin, N. K. (2015). Triangulation. The Blackwell Encyclopedia Of Sociology.doi: https://doi.Org/10.1002/9781405165518.

Ghasemi, B., \& Hashemi, M. (2011). Foreign Language Learning During Childhood. Procedia -Social And Behavioral Sciences, 28, 872-876. doi: https://doi.org/10.1016/J.Sbspro.2011.11.160

Jazuly, A. (2018). Guidance of Teaching English to Young Learners ( Teyl ) for Early Childhood Education Teachers at Ad Dhuha Kindergarten of Jember. Journal Of Linguistics, English Education And Art (Leea), 1(2), 168-179.

Jing, H., Xiaodong, H., \& Yu, L. (2016). Error Correction in Oral Classroom English Teaching, 9(12), 98-103. doi: https://doi.org/10.5539/elt.v9n12p98

Juhana. (2014). Teaching English to Young Learners: Some Points to be Considered. Asian Journal Of Education And E-Learning, 02(01), 43-46.

La Ode Turi, Jafar Ahiri, La Dunifa, L. A. (2017). Identifying the Problems of Indonesian Primary School. International Journal Of Education, Learning And Development, 5(8), 55-64.

Listyariani, N. P. R., Artini, L. P., \& Padmadewi, N. N. (2018). Teachers ' Perceptions of Teaching English for Young Learners and The Implementation in Public Primary Schools in Jembrana Sub-District. Jurnal Pendidikan Bahasa Inggris Indonesia, 6(2), 1-10.

Medwell, J., Wray, D., Minns, H., Coates, E., \& Griffiths, V. (2009). Primary English: Teaching Theory and Practice. Trowbridge: Cromwell Press Group Ltd.

Miles, M. (1994). Miles and Huberman Chapter 2. Qualitative Data Analysis, 5072 .

Padmadewi, N. N., Nitiasih, P. K., \& Artini, L. P. (2009). Model Konseptual Pembelajaran Bahasa Inggris Berbasis Budaya Untuk Sekolah Dasar Di Bali. Jurnal Pendidikan dan Pengajaran, 170-177. 
Patton, M. Q. (1999). Enhancing The Quality and Credibility of Qualitative Analysis. Health Services Research, 34(5), 1189-1208.

Peraturan Bupati Badung Nomor 43 Tahun 2016 tentang Mata Pelajaran Bahasa Inggris sebagai Muatan Lokal untuk Jenjang Pendidikan Sekolah Dasar/Madrasah Ibtidaiyah di Kabupaten Badung. Mangupura: Sekretariat Daerah Kabupaten Badung.

Pertiwi, R. S., Salabiyati, I., Damara, D., \& Pratolo, B. W. (2020). The Teacher's Perspectives about Challenges of Teaching English for Young Learners: A Case Study at English Course for Young Learners. Advances in Social Science, Education and Humanities Research, 397, 65-74. doi: https://doi.org/10.2991/assehr.k.200129.009

Putra, J. R. (2015). Creating A Positive English Language Teaching and Learning Environment In EYL Classroom Setting. Teylin2, (218), 218-261.

Rahayu, V. W. T. (2016). Teachers' Challenges in Teaching English to Young Learners in Rural Public Primary Schools in Salatiga.

Rusiana, R., \& Nuraeningsih, N. (2016). Teaching English to Young Learners through Traditional Games. Language Circle: Journal of Language and Literature, 10(2), 193-200.

Salmona Madriñan, M. (2014). The Use of First Language in the Second-Language Classroom: A Support for Second Language Acquisition. Gist Education and Learning research journal, 9, 50-66.doi: https://doi.org/10.26817/16925777.143

Sepyanda, M. (2017). The Importance of English Subject in Elementary School Curriculum. English Language Teaching And Research, 1(1), 206-216.

Shulman, L. S. (1986). Those who understand: Knowledge growth in teaching. Educational Researcher, 15(2), 4-14.

Sougari, A. M., \& Hovhannisyan, I. (2016). Investigating the Impact of Learning Conditions on Young Learners' Attitudes and Motivation to Learn English as a Foreign Language. Selected papers on theoretical and applied linguistics, 21, 743-758.

Swart, F., de Graaff, R., Onstenk, J., \& Knezic, D. (2018). Teacher Educators' Personal Practical Knowledge of Language. Teachers and Teaching: Theory and Practice, 24(2), 166-182. doi: https://doi.org/10.1080/13540602.2017.1368477

Uysal, N. D., \& Aydin, S. (2017). Foreign Language Teachers' Perceptions of Error Correction in Speaking Classes: A Qualitative Study. Qualitative Report, 22(1), 123-135. 